\title{
Daily sitting time and physical performance in oldest adults
}

http://dx.doi.org/10.11606/1807-5509201800010017

\author{
Lucélia Justino BORGES* \\ Renata da CONCEIÇÃO ${ }^{* *}$ \\ Vandrize MENEGHINI** \\ Tiago Rosa de SOUZA** \\ Aline Rodrigues BARBOSA** \\ * Departamento de \\ Educação Física, \\ Universidade Federal \\ do Paraná - Campus \\ Jardim Botânico, \\ Curitiba, PR, Brasil. \\ ${ }^{* *}$ Centro de \\ Desportos, \\ Universidade Federal \\ de Santa Catarina - \\ Campus Trindade, \\ Florianópolis, SC, \\ Brasil.
}

\begin{abstract}
The aim of this study was to verify the physical performance (PP) and daily sitting time in the oldest population in a rural community dwelling in southern Brazil. In addition, to analyze the association between physical performance tests (PPT) and daily sitting time (ST). This was a cross-sectional, population-based household study. All residents aged 80 years and older were examined in 2010. PPT included standing balance (four measures of static balance), five times "sit-to-stand" test and "pick up a pen" test (assessed by time). Daily ST was estimated by questionnaire. Women of the younger age groups displayed better results in the PPT compared to older women. The men had good results in the tests, independent from their age group (except for 95-100 years of age). For women, the mean time in the "sit to stand" test decreased with the advancing age, whereas for men, we observed the opposite. Men and women displayed similar means in the "pick up a pen" test. The mean daily ST increased with the advancement of age. After adjustment for sex, age, and number of morbidities, the daily ST was $\sim 52$ minutes lower for those with better balance $(\beta-52.6 ; p=0.001)$. For those with better performance in the "sit to stand" test, the time was $\sim 35$ minutes lower $(\beta-35.8 ; p=0.001)$. Men and women differ in the rate of decline in PPT. The results suggest that longer sitting time is a limiting factor of good performance in tests for the oldest of the population.
\end{abstract}

KEYWORDS: Sitting; Aging; Sedentary lifestyle; Physical performance; Time and motion studies.

\section{Introduction}

The longevity of the Brazilian population requires attention due to the increase in the number of people aged 80 or older ${ }^{1}$. The 2010 census revealed approximately three million Brazilian people in this age group, with 24,236 elderly persons over 100 years of age ${ }^{2}$. With aging comes chronic diseases and functional limitations, which are predictors of disability in older people ${ }^{3}$ reduce their quality of life ${ }^{4}$. Physical performance tests can assess functional limitations and make it possible to introduce actions to prevent or treat incapacities ${ }^{3}$ along with structured physical activity programs.

Physical activity levels are one of the aspects related to physical function ${ }^{5}$. Active older people have a lower risk of functional limitation and disability. Recently, Seguin et al. ${ }^{6}$ showed a strong association between sedentary time and diminished physical function. Interest in the health effects of sedentary behavior has increased in the last decade ${ }^{7}$, and the time spent sitting has recently been used to identify sedentary behavior $^{6,7}$. In Brazil, there have been few studies addressing time spent sitting among adults ${ }^{8}$ or only among older people 9 . Specifically, for the oldest population, no national studies were found relating physical performance tests and daily sitting time.

The objectives of this study were to assess the physical performance and daily sitting time in the oldest population in a rural community dwelling in southern Brazil. The population was examined according to sex and age group. Another objective was to analyze the association between physical performance tests and daily sitting time. 


\section{Method}

\section{Setting and study population}

This was a cross-sectional study based on baseline data from an epidemiological household-based population survey ("Effectiveness of health actions, physical activity and nutrition in older adults of Antônio Carlos - SC"). The survey was conducted with older adults ( $\geq 60$ years) residing in the municipality of Antônio Carlos (AC-SC), state of Santa Catarina, South of Brazil. Details about the setting and study population have already been published ${ }^{10}$ and will be presented in a shortened form. The municipality of AC-SC has a high human development index (HDI: 0.827) and is the biggest vegetable producer in Santa Catarina. In 2010, the population of AC-SC consisted of 7,458 inhabitants (12.8\% were 60 or over) and its population is mostly $(-70 \%)$ distributed across small farms ${ }^{2}$.

The present study utilizes data of all residents aged 80 years or older, identified by information from the Family Health Strategy Program (Portuguese acronym: ESF), in 2009. The ESF is a primary healthcare program that covers the whole municipality. Were identified 135 individuals, and this number is in accordance to Brazilian census data ${ }^{2}$. One person was absent during the data collection (criteria for sample loss), resulting in 134 attendees.

Data were collected using a form based on the questionnaire and physical tests of the SABE survey. The SABE survey was accomplished in Brazil and six more countries in Latin America and the Caribbean using validated instruments and was considered appropriate to identify what is relevant to the aging process in the region ${ }^{11}$.

Two trained interviewers collected the data during on home visit (February to April 2010) and the performance tests were conducted after the questionnaire. The older adult with cognitive impairment had a proxy informant (parent or caregiver) to answer the questions. The precision and accuracy of the physical performance measures were confirmed before the collection of data (intraobserver technical error $=0.93$; inter-observer technical error $=0.89$ ). The Human Beings Research Ethical Committee of the Universidade Federal de Santa Catarina (Case No. 189/09) approved the research. Participation was voluntary, and a signed informed consent form was obtained.

\section{Physical performance tests}

The older adults were excluded from analysis if they refused to take the tests or failed to understand the instructions due poor interpretation. Persons who were unable to perform the measurements due physical limitations were included in the analysis (unable category) and comprise the following: a) individuals who needed help to remain standing up or could not walk; b) those who had paralysis of a limb, used a prosthesis, or could not keep their balance; $c$ ) older adults who had undergone eye surgery (cataract or retina) in the past 6 weeks did not take the "pick up a pen" test.

The "five times sit to stand" test (a measure of functional lower limb muscle strength/resistance $)^{12}$ consisted of the time taken in seconds to rise five times from an armless chair (with crossed arms). This test was considered to be successfully accomplished when completed in $<60$ seconds. The classifications used were "unable" (time $>60$ seconds), "weak" (>16 to 60 seconds), "good" (>10 to 16 seconds), and "very good" ( $\leq 10$ seconds) $)^{3}$.

For the "pick up a pen" test (for mobility) ${ }^{13}$ the participants had to bend down, pick up a pen from the floor (at a distance of $30 \mathrm{~cm}$ from the tip of the toes), and return to the initial position within $\leq 30$ seconds. For this test, the classifications used were "unable" (time $>30$ seconds), "weak" (>6 to $\leq 30$ seconds), "good" ( $>2$ to $\leq 6$ seconds), and "very good" ( $\leq 2$ seconds) $)^{3}$.

Balance was determined by four measures ${ }^{12}$, performed in sequence (10 seconds each): side-byside stand; full tandem stand; one-leg (right) stand; and one-leg (left) stand. If the interviewee could not complete the first measure, the subsequent measures could not be completed. The classification for this test was taken from BARBosA et al. ${ }^{3}$.

\section{Daily sitting time}

Daily sitting time was measured by domain 5 of the International Physical Activity Questionnaire (IPAQ) ${ }^{14}$. This domain corresponds to the time that a person spends sitting down at different places (at home, community groups, and other places), doing activities such as craft work, watching television, reading, making phone calls, having meals, and resting. Sitting time was registered in minutes during 
one weekday and one weekend day. The final result was obtained according to the following calculation:

Total sitting time (minutes/week) $=$ Minutes sitting time on one weekday* 5 weekdays + Minutes sitting time on a weekend day ${ }^{*} 2$.

To ascertain the mean sitting time, the value obtained was divided by seven days of the week. Non-walking individuals $(n=21)$ were excluded from the statistical analyses for this variable.

Literacy (yes; no), living arrangement (alone; accomplished), number of morbidities $(0 ; 1 ; 2$ or more), and cognitive status (normal; altered) were used to characterize the population. A screening test (Mini Mental State Examination) ${ }^{15}$ verified the cognitive status.

\section{Statistical procedure}

For descriptive analysis of the variables, we used the mean, median, standard deviation, and proportion of individuals according to sex and age groups (80-84, 85-89, 90-94, and $\geq 95$ years). The associations between the dependent variable (sitting time) and the explanatory variables (physical performance tests) were carried out using multiple linear regression (crude and adjusted; 95\% confidence interval). The statistical program SPSS (version 16.0) was used to analyze the data. The significance level adopted was $\mathrm{p}<0.05$.

\section{Results}

The age of the participants $(n=134)$ varied from 80 to 100 years $(84.7 \pm 4.6$ years $)$. The mean ages were $85 \pm 4.3$ years among men and $84.4 \pm 4.7$ years among women. The sample comprised mostly women, individuals with no cognitive impairment, and individuals with 2 or more morbidities (TABLE 1).

TABLE 1 - Distribution (\%) of older adults for sex according to socio-demographic and health conditions.

\begin{tabular}{lccccc}
\hline & \multicolumn{2}{c}{ Men } & & \multicolumn{2}{c}{ Women } \\
\cline { 2 - 3 } \cline { 5 - 6 } Age (years) & $\boldsymbol{n}$ & $\%$ & & $\boldsymbol{n}$ \\
$80-84$ & 33 & 58.9 & 52 & 66.7 \\
$85-89$ & 14 & 25.0 & 15 & 19.2 \\
$90-94$ & 08 & 14.3 & 05 & 6.4 \\
$95-100$ & 01 & 1.8 & & 06 & 7.7 \\
\hline Literacy & & & & \\
Yes & 42 & 75.0 & 69 & 88.5 \\
No & 14 & 25.0 & 09 & 11.5 \\
\hline Living arrangement & & & & \\
Alone & 06 & 10.7 & 17 & 21.8 \\
Accompanied & 50 & 89.3 & 61 & 78.2 \\
\hline Cognitive Status & & & & \\
Cognitive deficit & 11 & 19.6 & 25 & 32.1 \\
No cognitive deficit & 45 & 80.4 & 53 & 67.9 \\
\hline Number of morbidity & & & & \\
0 & 12 & 22.6 & 08 & 10.3 \\
1 & 17 & 32.1 & 24 & 30.8 \\
2 or more & 24 & 45.3 & 46 & 58.9 \\
\hline
\end{tabular}


${ }^{*} n=54 \quad{ }^{* *} n=55$

tWomen: non-walking

individuals were

excluded $(n=15)$

t'Men: non-walking

individuals were

excluded $(n=6)$
Women of the younger age groups displayed better results in the physical performance tests compared to older women. The men had good results in the tests, independent from their age group, except for the oldest man (95-100 years of age) who was classified as "unable." The lowest daily sitting time (median of 1,845 minutes/week or 4 hours/day) was observed in younger men and women (80-84 age group) (TABLE 2).

TABLE 2 - Physical performance tests and daily sitting time according to age and sex.

\begin{tabular}{|c|c|c|c|c|c|c|c|c|}
\hline & \multicolumn{2}{|c|}{$80-84 y$} & \multicolumn{2}{|c|}{$85-89$ y } & \multicolumn{2}{|c|}{$90-94 y$} & \multicolumn{2}{|c|}{$95-100 y$} \\
\hline & $n$ & $\%$ & $n$ & $\%$ & $n$ & $\%$ & $\mathbf{n}$ & $\%$ \\
\hline \multicolumn{9}{|l|}{ Women } \\
\hline \multicolumn{9}{|l|}{ Sit to stand } \\
\hline Unable & 15 & 28.8 & 04 & 28.6 & 03 & 60.0 & 03 & 50.0 \\
\hline Weak & 15 & 28.8 & 02 & 14.3 & 01 & 20.0 & 01 & 16.7 \\
\hline Good & 16 & 30.9 & 07 & 50.0 & 01 & 20.0 & 02 & 33.3 \\
\hline Very good & 06 & 11.5 & 01 & 7.1 & - & - & - & - \\
\hline \multicolumn{9}{|l|}{ Pick up a pen } \\
\hline Unable & 11 & 21.2 & 04 & 26.7 & 03 & 60.0 & 02 & 33.4 \\
\hline Weak & 04 & 7.7 & - & - & - & - & 02 & 33.3 \\
\hline Good & 36 & 69.2 & 11 & 73.3 & 02 & 40.0 & 02 & 33.3 \\
\hline Very good & 01 & 1.9 & - & - & - & - & - & - \\
\hline \multicolumn{9}{|l|}{ Balance } \\
\hline Unable & 08 & 15.4 & 04 & 26.7 & 03 & 60.0 & 02 & 33.4 \\
\hline Weak & 10 & 19.2 & 03 & 20.0 & 02 & 40.0 & 02 & 33.3 \\
\hline Good & 23 & 44.2 & 03 & 20.0 & - & - & 02 & 33.3 \\
\hline Very good & 11 & 21.2 & 05 & 33.3 & - & - & - & - \\
\hline \multicolumn{9}{|c|}{ Daily sitting time $^{\dagger}$} \\
\hline$<4$ hours/Day & 23 & 52.3 & 06 & 46.2 & - & - & 01 & 25.0 \\
\hline$\geq 4$ hours/Day & 21 & 47.7 & 07 & 53.8 & 02 & 100.0 & 03 & 75.0 \\
\hline \multicolumn{9}{|l|}{ Men } \\
\hline \multicolumn{9}{|l|}{ Sit to stand* } \\
\hline Unable & 03 & 9.1 & 03 & 25.0 & 02 & 25.0 & 01 & 100.0 \\
\hline Weak & 06 & 18.2 & 01 & 8.3 & 03 & 37.5 & - & - \\
\hline Good & 16 & 48.5 & 07 & 58.3 & 03 & 37.5 & - & - \\
\hline Very good & 08 & 24.2 & 01 & 8.3 & - & - & - & - \\
\hline \multicolumn{9}{|l|}{ Pick up a pen** } \\
\hline Unable & 01 & 3.0 & 03 & 23.1 & 02 & 25.0 & 01 & 100.0 \\
\hline Weak & 02 & 6.1 & - & - & - & & - & - \\
\hline Good & 29 & 87.9 & 09 & 69.2 & 06 & 75.0 & - & - \\
\hline Very good & 01 & 3.0 & 01 & 7.7 & - & - & - & - \\
\hline \multicolumn{9}{|l|}{ Balance } \\
\hline Unable & 01 & 3.0 & 03 & 21.4 & 02 & 25.0 & 01 & 100.0 \\
\hline Weak & 02 & 6.1 & 01 & 7.1 & 01 & 12.5 & - & - \\
\hline Good & 08 & 24.2 & 06 & 42.9 & 02 & 25.0 & - & - \\
\hline Very good & 22 & 66.7 & 04 & 28.6 & 03 & 37.5 & - & - \\
\hline \multicolumn{9}{|c|}{ Daily sitting time ${ }^{\dagger \dagger}$} \\
\hline$<4$ hours/day & 20 & 62.5 & 02 & 18.2 & 04 & 66.7 & - & - \\
\hline$\geq 4$ hours/day & 12 & 37.5 & 09 & 81.8 & 02 & 33.3 & 01 & 100.0 \\
\hline
\end{tabular}


For women, the mean time in the "five times sit to stand" test decreased with the advancing age, whereas for men, we observed the opposite. In relation to the "pick up the pen" test, the men and women displayed similar means in all age groups. For daily sitting time, the mean was 1,908.9 minutes/week ( \pm 784.6). The groups of women aged 90-94 years and 80-84 years had the highest and lowest means, respectively (TABLE 3 ). The mean daily sitting time increased with the advancement of age for both sexes.
The daily sitting time showed an association with the "five times sit to stand" test and the balance test (TABLE 4). After adjustment for sex, age, and number of morbidities, the daily sitting time was -52 minutes lower for those with better balance $(\beta-52.6$; 95\%IC: $-78,8$ to $-26.3 ; p=0.001)$. For those with better performance in the "five times sit to stand" test, the time was -35 minutes lower ( $\beta$-35.8; 95\%IC: -59.7 to $-11.9 ; \mathrm{p}=0.001)$.

TABLE 3 - Mean $(\overline{\mathrm{X}})$ and standard deviation (DP) of the physical performance tests (seconds) and daily sitting time (minutes) according to age and sex.

\begin{tabular}{|c|c|c|c|c|c|c|c|c|c|c|c|c|}
\hline & \multicolumn{3}{|c|}{$80-84 y$} & \multicolumn{3}{|c|}{$85-89 y$} & \multicolumn{3}{|c|}{$90-94 y$} & \multicolumn{3}{|c|}{$95-100 y$} \\
\hline & $n$ & $\overline{\mathbf{X}}$ & SD & $n$ & $\overline{\mathbf{X}}$ & SD & $n$ & $\overline{\mathbf{X}}$ & SD & $n$ & $\overline{\mathbf{X}}$ & SD \\
\hline \multicolumn{13}{|l|}{ Women } \\
\hline Sit to stand & 37 & 15.4 & 6.2 & 10 & 14.5 & 5.0 & 02 & 13.0 & 4.2 & 03 & 13.7 & 2.5 \\
\hline Pick up a pen & 41 & 3.4 & 2.1 & 11 & 2.7 & 0.6 & 02 & 3.5 & 2.1 & 04 & 4.5 & 1.9 \\
\hline $\begin{array}{l}\text { Daily Sitting time } \\
\text { (minutes/week) }\end{array}$ & 50 & 1958.9 & 718.9 & 15 & 1996.1 & 911.6 & 05 & 2730.0 & 96.9 & 06 & 2310.0 & 999.8 \\
\hline \multicolumn{13}{|l|}{ Men } \\
\hline Sit to stand & 30 & 12.5 & 4.3 & 09 & 12.3 & 2.5 & 06 & 16.5 & 7.1 & 01 & - & - \\
\hline Pick up a pen & 32 & 2.8 & 1.4 & 10 & 2.2 & 0.6 & 06 & 2.7 & 1.2 & & - & - \\
\hline $\begin{array}{l}\text { Daily Sitting time } \\
\text { (minutes/week) }\end{array}$ & 33 & 1599.5 & 732.9 & 14 & 2138.2 & 548.8 & 08 & 1660.0 & 711.6 & 01 & $4200.0^{*}$ & - \\
\hline
\end{tabular}

TABLE 4 - Analysis of linear regression to test the association between each physical performance test and daily sitting time.

\begin{tabular}{lccccc}
\hline & \multicolumn{2}{c}{ Crude } & & \multicolumn{2}{c}{ Adjusted $^{*}$} \\
\cline { 2 - 3 } \cline { 5 - 6 } & $\beta(\mathbf{9 5} \% \mathbf{C I})$ & $\mathbf{p}$-value & & $\beta(\mathbf{9 5 \%} \mathbf{C I})$ & p-value \\
\hline Sit to stand & $-41.6(-64.4$ to -18.8$)$ & 0.001 & & $-35.8(-59.7$ to -11.9$)$ & 0.001 \\
Pick up a pen & $-35.8(-71.2$ to 0.4$)$ & 0.048 & & $-26.6(-62.9$ to 9.5$)$ & 0.147 \\
Balance & $-55.8(-78.8$ to -32.8$)$ & 0.001 & & $-52.6(-78.8$ to -26.3$)$ & 0.001 \\
\hline
\end{tabular}

* Adjusted for sex. age group and morbidities. Cl 95\%: Confidence interval $95 \%$.

\section{Discussion}

To our knowledge, this is the first population and household-based study carried out with the oldest age group from rural and urban areas in Brazilian and investigating the association between physical performance and sitting time. The time spent sitting can be an alternative to long questionnaires on physical activity levels to ascertain sedentary behavior, especially in epidemiological studies. The results of the present study showed that younger women had good results in the physical performance tests, whereas the men of all age groups had good results in all tests. This data is similar to the results of other investigations ${ }^{3,16,17}$. The difference between the sexes may be explained by the greater life expectancy of women that display a higher number of morbidity and health complications which can lead to functional limitation ${ }^{18}$. Furthermore, men are more often employed in jobs involving physical activities such as farming ${ }^{10}$, which favors the maintenance of physical performance.

${ }^{*}$ Total value in minutes/week ( $n=1)$

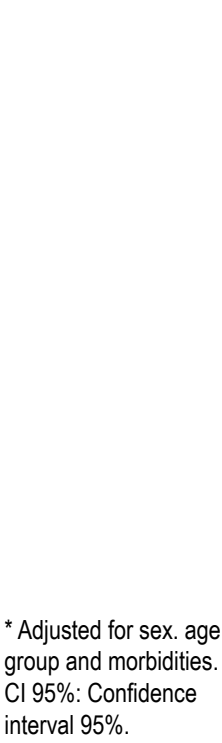


In the present study, only women showed a reduction in motor performance with advancing age, in contrast to previous studies ${ }^{19,20}$. The advancing age increases the degree of impairment and compromises physical performance ${ }^{3}$. The good performance of men of all ages may be related to survival bias or to shorter time spent in sedentary activities. In relation to daily sitting time, women of the 90-94 age group presented the highest daily sitting time, whereas the younger group (80 to 84 years) had the lowest mean. Our results are consistent with previous studies ${ }^{9,21,22}$, which indicate increasing daily sitting time with the advancement of age. The increase in time spent in sedentary behaviors may reflect an increase of comorbitidies $^{22}$, a decrease of functional capacity ${ }^{4}$ and an increase of physical incapacity ${ }^{3,6,12}$.

The results of the mean daily sitting time were similar to previous studies ${ }^{8,23,24}$. The daily sitting time considered healthy or unhealthy for older people has not been established ${ }^{9}$. However, the identification of the time that older adults spend sitting can help in the development of actions to reduce sedentary behavior. The adjusted analyses identified an association between lower daily sitting time and better physical performance in the balance and "five times sit to stand" tests. In a study by SEGUIN et al. ${ }^{6}$, women who reported the largest amounts of sedentary time presented higher physical function compared to those reporting less sedentary time. These results support the deleterious health outcomes of higher time spent sitting on physical function and performance. Daily sitting time should be taken into consideration when assessing the functional limitations of the oldest of the population. Among the limitations, we highlight that the study design does not allow for an inference of cause and effect relationships. The indirect measure of daily sitting time can be a limitation, as it takes memory bias into consideration. Furthermore, we highlight that although the IPAQ has been validated and is used in different countries, it has been used more often to assess the total level of physical activity rather than to assess sitting time.

The results give evidence for better physical performance with younger women, whereas for men, age did not influence physical performance, and all age groups displayed good results. Older adults from the youngest age group (80-84 years) showed the lowest means of time spent sitting, and women from the oldest age group (90-94 years) displayed the highest mean. Older people who remained seated for longer periods displayed the poorest results in the "five times sit to stand" and balance tests. The results suggest that longer sitting time is a limiting factor of good performance in tests for the oldest of the population. However, more studies are needed in a range of settings because of varying lifestyles. Due to the limitations of the present study, we also recommend longitudinal studies, direct assessment of sedentary behavior, and the use of different motor performance tests.

\section{Resumo}

\section{Tempo sentado e desempenho motor em idosos longevos}

Objetivou-se verificar o desempenho motor e o tempo sentado, bem como a associação entre essas variáveis em idosos longevos, residentes em um município do sul do Brasil. Estudo transversal e de base domiciliar, realizado em 2010 com idosos de 80 anos ou mais. 0 desempenho motor foi avaliado pelos testes: "sentar e levantar" e "agachar e pegar o lápis" (avaliados por tempo) e "equilibrio" (quatro medidas de equilibrio estático). A avaliação do tempo gasto sentado foi realizada por questionário. Os resultados mostraram que mulheres dos grupos etários mais jovens apresentaram melhores resultados nos testes de desempenho motor. Os homens tiveram bons resultados nos testes, independente do grupo etário (exceto para o grupo 95-100 anos). Para as mulheres, o tempo médio no teste "sentar e levantar" diminuiu com o avanço da idade, observando o contrário para os homens. Homens e mulheres tiveram resultados semelhantes para o teste "agachar e pegar o lápis". A média diária do tempo sentado aumentou com o avanço da idade. Após o ajuste para sexo, idade e número de morbidades, a média do tempo sentado diário foi, aproximadamente, 52 minutos menor para os idosos com melhor equilibrio $(\beta-52,6 ; p=0,001)$ e 35 minutos menor $(\beta-35,8 ; p=0,001)$ para os idosos com melhor desempenho no teste "sentar e levantar". Homens e mulheres diferem quanto ao declínio nos 
testes de desempenho motor. Os resultados sugerem que, em idosos longevos, o maior tempo sentado é limitante para o bom desempenho nos testes.

Palavras-chave: Tempo sentado; Envelhecimento; Estilo de vida sedentário; Desempenho motor; Estudos de tempo e movimento.

\section{References}

1. Instituto Brasileiro de Geografia e Estatística (IBGE). Síntese dos indicadores sociais: uma análise das condições de vida da população brasileira [Internet]. Rio de Janeiro, 2013 [cited 2014 Sep 28]. Available from: https://bit.ly/2oFgIKP.

2. Instituto Brasileiro de Geografia e Estatística (IBGE). Censo Demográfico 2010. Características da população e dos domicílios: Resultados do Universo [Internet]. Rio de Janeiro, 2011 [cited 2014 Sep 28]. Available from: https://bit.ly/2kwSUnv.

3. Barbosa AR, Souza JMP, Lebrão ML, Laurenti R, Marucci MFN. Functional limitations of brazilian elderly by age and gender differences: data from SABE Survey. Cad Saúde Pública. 2005;21(4):1177-85.

4. Santos JLF, Lebrão ML, Duarte YAO, Lima FDL. Functional performance of the elderly in instrumental activities of daily living: an analysis in the municipality of São Paulo, Brazil. Cad Saúde Pública. 2008; 24(4):879-86.

5. Buchner DM. Physical activity to prevent or reverse disability in sedentary older adults. Am J Prev Med. 2003;25(3 Suppl 2):214-5.

6. Seguin R, La Monte M, Tinker L, Liu J, Woods N, Michael YL, et al. Sedentary behavior and physical function decline in older women: findings from the Women's Health Initiative. J Aging Res; 2012:1-10.

7. van Uffelen JGZ, Heesch KC, Hill RL, Brown WJ. A qualitative study of older adults' responses to sitting-time questions: do we get the information we want? BMC Public Health. 2011;11:458.

8. Suzuki CS, Moraes SA, Freitas ICM. Média diária de tempo sentado e fatores associados em adultos residentes no município de Ribeirão Preto-SP, 2006: Projeto OBEDIARP. Rev Bras Epidemiol. 2010;13(4):699-712.

9. Monego EA, Barbosa AR. Factors associated with daily sitting time in a rural community-dwelling of older adults from southern Brazil. Rev Bras Ativ Fis e Saúde. 2014;19(3):371-81.

10. Confortin SC, Barbosa AR, Danielewicz AL, Meneghini V, Testa W. Motor performance of elderly in a community in southern Brazil. Rev Bras Cineantropom Desempenho Hum. 2013;15(4):417-26.

11. Albala C, Lebrão ML, León-Díaz EM, Ham-Chande R, Hennis AJ, Palloni A, et al. Encuesta Salud, Bienestar y Envejecimiento (SABE): metodología de la encuesta y perfil de la población estudiada. Rev Panam Salud Publica. 2005;17(5/6):307-22.

12. Guranilk JM, Ferruci L. Assessing the building blocks of function: utilizing measures of functional limitation. Am J Prev Med. 2003;25(3 Suppl 2):112-21.

13. Reuben DB, Siu AL. An objective measure of physical function of elderly outpatients: the physical performance test. J Am Geriatr Soc. 1990;38(10):1105-12.

14. Craig CL, Marshall AL, Sjöström M, Bauman AE, Booth ML, Ainsworth BE, et al. International physical activity questionnaire: 12-country reliability and validity. Med Sci Sports Exerc. 2003;35(8):1381-95.

15. Bertolucci PHF, Brucki SMD, Capacci SR, Juliano Y. The mini-mental state examination in an outpatient population: influence of literacy. Arq Neuro-Psiquiatr. 1994;52(1):1-7.

16. Orfila F, Ferrer M, Lamarca R, Tebe C, Domingo-Salvany A, Alonso J. Gender differences in health-related quality of life among the elderly: The role of objective functional capacity and chronic conditions. Soc Sci Med. 2006;63(9):2367-80.

17. Tanaka H, Seals DR. Age and gender interactions in physiological functional capacity: insight from swimming performance. J Appl Physiol. 1997;82(3):846-51.

18. Abegunde DO, Mathers CD, Adam T, Ortegon M, Strong K. The burden and costs of chronic diseases in low-income and middle-income countries. Lancet. 2007;370(9603):1929-38.

19. Rodrigues-Barbosa A, Miranda LM, Vieira-Guimarães A, Xavier-Corseuil H, Weber-Courseuil M. Age and gender differences regarding physical performance in the elderly from Barbados and Cuba. Rev Salud Pública (Bogotá). 2011;13(1):54-66.

20. Pinheiro PA, Passos TD'EO, Coqueiro RS, Fernandes MH, Barbosa AR. Motor performance of the elderly in northeast Brazil: differences with age and sex. Rev Esc Enferm USP. 2013;47(1):125-33.

21. Evenson KR, Buchner DM, Morland KB. Objective measurement of physical activity and sedentary behavior among U.S. adults aged 60 years or older. Prev Chronic Dis. 2012;9, 1-10. 
22. Matthews CE, Chen KY, Freedson PS, Buchowski MS, Beech BM, Pate RR, et al. Amount of time spent in sedentary behaviors in the United States, 2003-2004. Am J Epidemiol. 2008;167(7):875-81.

23. Thorp AA, Healy GN, Owen N, Salmon J, Ball K, Shaw JE, et al. Deleterious associations of sitting time and television viewing time with cardiometabolic risk biomarkers: Australian diabetes, obesity and lifestyle (AusDiab) study 2004-2005. Diabetes Care. 2010;33(2):327-34.

24. Bauman A, Ainsworth BE, Sallis JF, Hagströmer M, Craig CL, Bull FC, et al. The descriptive epidemiology of sitting: a 20-country comparison using the International Physical Activity Questionnaire (IPAQ). Am J Prev Med. 2011;41(2):228-35.

\section{Conflict of interest}

The authors declare that there are no conflicts of interest.

\section{Acknowledgements}

The authors want to thank Antonio Carlos' Board of Health and Social Assistance, the health agents and the attendees on this research. This research was supported by the Brazilian National Council of Technological and Scientific Development (CNPq- Process 478073/2009-7). The authors want to thank Coordination of Improvement of Higher Education (CAPES) and National Council of Technological and Scientific Development (CNPq-PIBIC) from received a doctoral scholarship and scholarship, respectively.

Lucélia Justino Borges Universidade Federal do Paraná Departamento de Educação Física -

Campus Jardim Botânico

Rua Coração de Maria, 92 - Jardim Botânico 80210.132 - Curitiba - PR - BRASIL e-mail: luceliajb@yahoo.com.br
Submitted: 12/05/2015

Revised: 29/07/2015

Accepted: 06/11/2015 